\title{
Middle Triassic gastropods from the Besano Formation of Monte San Giorgio, Switzerland
}

Vittorio Pieroni ${ }^{1}$ and Heinz Furrer ${ }^{2^{*}}$

\begin{abstract}
For the first time gastropods from the Besano Formation (Anisian/Ladinian boundary) are documented. The material was collected from three different outcrops at Monte San Giorgio (Southern Alps, Ticino, Switzerland). The taxa here described are Worthenia (Humiliworthenia)? aff. microstriata, Frederikella cf. cancellata, ?Trachynerita sp., ?Omphaloptycha sp. 1 and ?Omphaloptycha sp. 2. They represent the best preserved specimens of a larger collection and document the presence in this formation of the clades Vetigastropoda, Neritimorpha and Caenogastropoda that were widespread on the Alpine Triassic carbonate platforms. True benthic molluscs are very rarely documented in the Besano Formation, which is interpreted as intra-platform basin sediments deposited in usually anoxic condition. Small and juvenile gastropods could have been lived as pseudoplankton attached to floating algae or as free-swimming veliger planktotrophic larval stages. Accumulations of larval specimens suggest unfavorable living conditions with prevailing disturbance in the planktic realm or mass mortality events. However, larger gastropods more probably were washed in with sediments disturbed by slumping and turbidite currents along the basin edge or storm activity across the platform of the time equivalent Middle San Salvatore Dolomite.
\end{abstract}

Keywords: Gastropods, Middle Triassic, Environment, Besano Formation, Southern Alps, Switzerland

\section{Introduction}

The Middle Triassic Besano Formation (formerly called "Grenzbitumenzone" in most publications) is exposed in the Monte San Giorgio area, across the boundary of Southern Switzerland (Canton Ticino) and Northern Italy (Province Varese), was registered in 2003 as a UNESCO World Heritage Site because of its important vertebrate fauna from the Middle Triassic (Furrer 2003). However, invertebrate fossils are also relatively common in this formation and some of the main clades of marine molluscs such as ammonoids, coleoids and bivalves (especially the genus Daonella) have been documented, notably by Airaghi (1911, 1912), Rieber (1965, 1968, 1969, 1970, 1973a, b, 1974a, b) and Schatz (2005a, b). They represent mostly nektonic cephalopods or bivalves adapted to an

\section{Editorial handling: D. Marty.}

*Correspondence: heinz.furrer-paleo@bluewin.ch

${ }^{2}$ Paläontologisches Institut und Museum der Universität Zürich, Karl

Schmid-Strasse 4, 8006 Zurich, Switzerland

Full list of author information is available at the end of the article environment characterized by anoxic condition in bottom waters of an intraplatform basin (Bernasconi 1991; Schatz 2005a). Findings of benthic molluscs, which are abundant on carbonate platforms, are scarce in this environment. In particular macrofossils such as gastropods are relatively rare and usually poorly preserved in the Besano Formation. Bassani (1886) provided the first report of gastropods from this formation and assigned his single specimen to Chemnitzia sp., giving only a description without illustration. This poorly preserved specimen had a turriculate shape, but its location is now uncertain. Rieber (1973b) also cited some unassigned turriculate gastropods from Monte San Giorgio (Point 902, "lower Grenzbitumenzone"), and Röhl et al. (2001: Fig. 4) documented the relative abundance of gastropods in the section of the Besano Formation ("Grenzbitumenzone") during the largest excavation at Point 902/Mirigioli from 1950-1965 by the University of Zurich. Furrer and Vandelli (2014, fig. p. 64) figured specimen PIMUZ 29952 as an indeterminate gastropod. Two specimens probably belonging to Coelostylinidae are figured by López-Arbarello et al. (2016, p. 
30/61, Fig. 18A) in association with a fish from the Upper Besano Formation of Mirigioli.

Here we document for the first time identifiable gastropods from the Besano Formation (Anisian/Ladinian boundary) of Monte San Giorgio (Canton Ticino, Southern Switzerland). The gastropod material illustrated here comes from the most important collection of Besano Formation fossils housed in the Paläontologisches Museum der Universität Zürich, with one specimen from the Museo Cantonale di Storia Naturale Lugano.

\section{Locations and age}

Four of the described specimens herein come from the site referred to as Point 902 or Mirigioli (Meride, today part of the community Mendrisio, Canton Ticino), located $800 \mathrm{~m}$ WSW of Monte San Giorgio, where the biggest paleontological excavation was done in the Besano Formation from 1950 to 1965 under direction of Emil Kuhn-Schnyder from the University of Zurich. About 600, mostly small gastropods were registered in the inventory during the bed-by-bed excavation (Fig. 1), together with the famous vertebrate remains, cephalopods, bivalves, dasycladacean algae and terrestrial plants (Rieber 1973a). The four described specimens were found in the lower and middle Besano Formation with a late Anisian age (Reitzi and Secedensis Zone). One single specimen comes from an outcrop of the middle Besano Formation close to the old mine in the Val Porina Valley, $750 \mathrm{~m} \mathrm{SW}$ of Monte San Giorgio. Accumulations of small turriculate gastropods derive from Point 902/Mirigioli and the old mine Valle Stelle (Tre Fontane), 1300 m WSW of Monte San Giorgio.

\section{Materials and methods}

The described gastropods from the Besano Formation are preserved usually as external molds covered or partially filled with dolomite crystals (Fig. 2). The molds are not deformed in shape which allowed silicon casts to be produced for the study. Some specimens are also preserved as internal molds. HF used also unpublished data referring to gastropods from the PIMUZ excavations at Monte San Giorgio.

\section{Institutional abbreviations}

MCSN: Museo Cantonale di Storia Naturale, Lugano, Switzerland

PIMUZ: Paläontologisches Institut und Museum der Universität Zürich, Switzerland

\section{Systematic palaeontology}

Vetigastropoda Salvini-Plawen, 1980

Basal gastropod taxa not assigned to order

Superfamily Trochonematoidea Zittel, 1895

Family Lophospiridae Wenz, 1938
Genus Worthenia de Koninck, 1883

Type species. Turbo tabulatus Conrad, 1835

Subgenus Worthenia (Humiliworthenia) Yin \& Yochelson, 1983

Type species. Worthenia nuda Koken, 1900, Middle Triassic, Ladinian, China.

Worthenia (Humiliworthenia)? aff. microstriata Nützel, Kaim \& Grădinaru, 2018 Fig. 3a-d

aff. 2018 Worthenia (Humiliworthenia) microstriata Nützel, p. 11, Fig. 10A-I.

Material Specimen MCSN 3002, preserved as external mold covered with fine dolomite crystals.

Measurements The spire consists of c. 6 whorls and is $20.82 \mathrm{~mm}$ high (first whorls missing) and $14.25 \mathrm{~mm}$ wide; spire angle $50^{\circ}$.

Occurrence Val Porina (750 m SW Monte San Giorgio, at 812 m.a.s.l.), Meride, Canton Ticino. Middle Besano Formation, uppermost Anisian.

Description The specimen MCSN 3002 shows a gradate, slightly pagodiform shell with whorls having two angulations, both with a strong spiral crest-like carina; the adapical carina is at the angle between the ramp and the outer whorl face, at about mid-height of the whorl, forming the periphery; the abapical carina is broader but less pronounced than the upper one; it is situated just in suprasutural position and forms edge towards base. The ramp is steeply inclined and convex, with a faint but distinct spiral cord at mid-height. The growth lines are strongly prosocline and slightly prosocyrt between the upper suture and the midwhorl angulation, where the selenizone seems to be present. The outer face between the spiral carinae is concave, and almost parallel to shell axis. The base is flatly conoidal; its wall is convex and smooth with slightly opisthocyrt and orthocline growth lines, and has a rather broad umbilicus. The umbilicus is surrounded by an angular rim.

Discussion The available specimen seems to be closely related to Worthenia (Humiliworthenia) microstriata Nützel et al. 2018, differing in having a broad umbilicus. Worthenia (Humiliworthenia) Yin \& Yochelson 1983 is also characterised by the absence of any axial ornament and a smooth surface except for crest-like angulations and a fine spiral striation. These are seen in the specimen on hand, although the growth lines are poorly preserved.

Order Trochida Rafinesque, 1815

Superfamily Trochoidea Rafinesque, 1815 


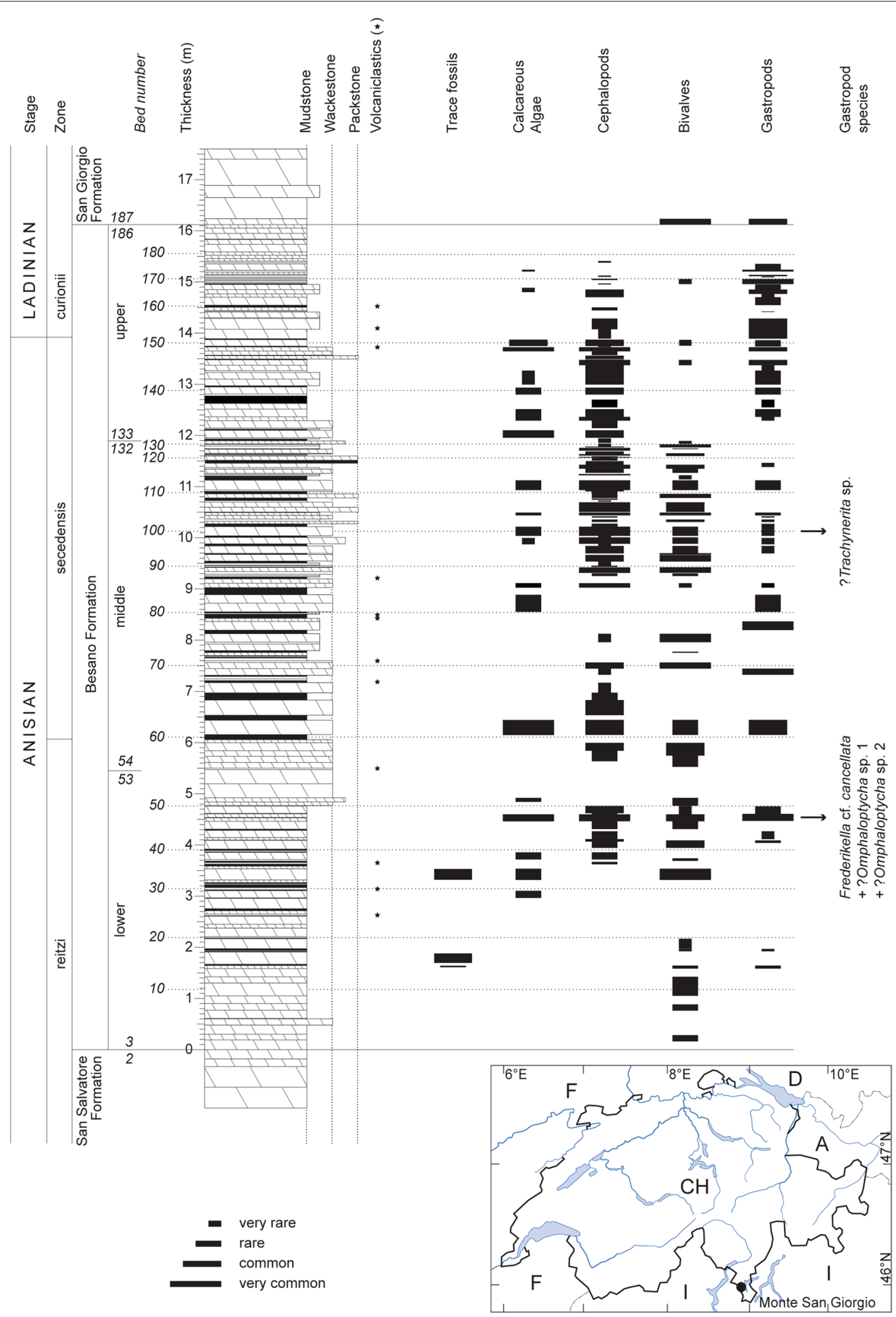

Fig. 1 Stratigraphic section of the Besano Formation at site Point 902/Mirigioli, with distribution and relative abundance of trace fossils, calcareous algae, cephalopods, bivalves and gastropods. Modified after Röhl et al. 2001 (Fig. 4), based on the internal inventory of the PIMUZ collection. The stratigraphic positions of four described specimens are indicated 


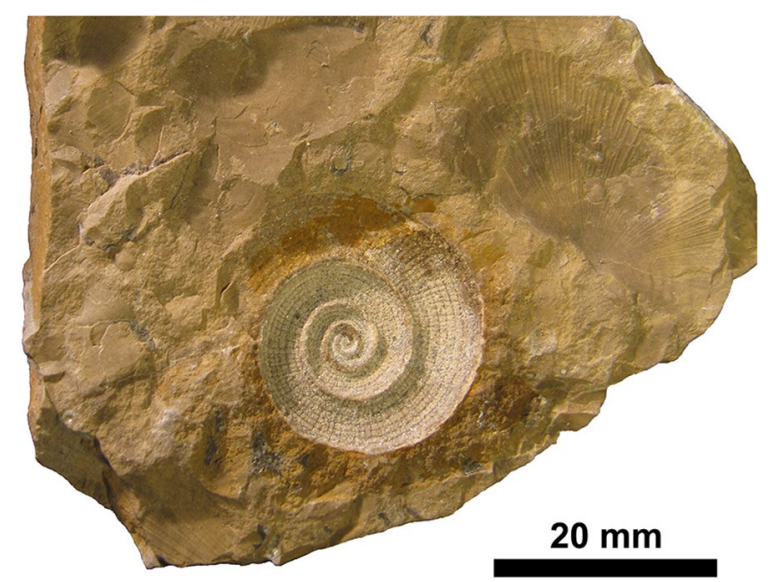

Fig. 2 Frederikella cf. cancellata (Zardini 1978). The original specimen PIMUZ 29952 with external mold (apical side) in association with Daonella cf. angulata Rieber 1968. Point 902/Mirigioli (Monte San Giorgio), Lower Besano Formation (bed 47)

Family Liotiidae Gray, 1850

Subfamily Liotiinae Gray, 1850

Genus Frederikella Bandel, 1993

Type species. Brochidium cancellatum Zardini, 1978

Frederikella cf. cancellata (Zardini, 1978) Fig. 3e-h cf. 1978 Brochidium cancellatum Zardini: p. 24, pl. 8, Fig. 12.

cf. 1993 Frederikella cf. cancellata (Zardini): Bandel, 1993, p. 10, pl. 2, Figs. 3, 4.

Material Specimen PIMUZ 29952, preserved partially as external mold covered with fine dolomite crystals, and partially as internal mold covered by shell (small portion of last whorl).

Measurements $\mathrm{D} \max =25.48 \mathrm{~mm}, 4$ whorls. At $\mathrm{D}=21 \mathrm{~mm}: \mathrm{H}=8.66 \mathrm{~mm} ; \mathrm{O}=9.43 ; \mathrm{O} \% \mathrm{D}=44.9$; pleural angle $=165^{\circ} ; \mathrm{H}$ of whorl $=7.33$, corresponding inner whorl $\mathrm{H}=3.98$ (measurements obtained from silicon cast, slightly incomplete in the peripheral area).

Occurrence Point 902/Mirigioli (800 m WSW Monte San Giorgio), Meride, Canton Ticino. Lower Besano Formation (bed 47, in association with Daonella cf. angulata Rieber, 1968), Reitzi Zone, uppermost Anisian.

Description The specimen PIMUZ 29952 shows a very low-spired, widely phaneromphalous shell with very slightly elevated spire. The whorls are well rounded. The spire has deeply impressed suture, numerous thick spiral threads and collabral riblets forming a network. About 19 regularly spaced, thick threads are present on the last whorl between the suture and the rim of the umbilicus. Slightly above the periphery two of these (the seventh and the eighth from the adapical suture) appear sharper and almost fused together, while, below and above, the others are more widely spaced. The six adapical spiral lines are crossed by densely and regularly distributed collabral riblets, which form knobby intersections. The spiral and radial lines are hardly visible on the base, because of poor preservation. Gentle nodes or folds are present on the rounded umbilical wall.

Discussion Bandel (2016) compared the genus Frederikella Bandel, 1993 with modern Liotiinae Gray, 1850. This genus was based on Frederikella cancellata (Zardini, 1978) from the San Cassiano Formation as documented by Bandel (1993, pl. 2, Figs. 2-4). The holotype described by Zardini (1978) is represented by a very small shell (less than 3 millimetres), and the juvenile specimen described by Bandel (1993) measures only $1.4 \mathrm{~mm}$ in diameter. The present specimen differs from the shells from the San Cassiano Formation in the much larger dimensions, the disposition of spiral elements at periphery and the presence of nodes/folds on the umbilical wall. However, because of the scarcity of specimens, the intraspecific and ontogenetic variability of this form is unknown. The species Frederikella axialocostata Gründel, 1998 (Dogger of Germany) strongly differs from the present one mainly because of its higher spire and narrower umbilicus. The genus Klebiella Gründel, 1998 differs in having a completely planispiral conch, and more evident and dense axial collabral riblets. In the present specimen, a presence of a selenizone is not completely excluded by the direction of the collabral ribblets. Unfortunately the peripheral region is not so well preserved.

Neritimorpha Golikov \& Starobogatov, 1975

Order Neritoina Rafinesque, 1815

Superfamily Neritoidea Rafinesque, 1815

Family Neritariidae Wenz, 1938

Subfamily Neritariinae Wenz, 1938

Genus Trachynerita Kittl, 1894b

Type species. This genus is based on Turbo quadratus Stoppani, 1858 (Esino Limestone $)=$ Trachynerita fornoensis Kittl, 1894b (Marmolada Limestone). Kittl established this genus in his Marmolada paper (1894b, pp. $120,133)$ and it is accepted by Böhm in his paper on the same fauna (1895, p. 239), as well as by Cossmann (1915, p. 185) and Wenz (1938, p. 415). Cossmann (1915) designated T. fornoensis as the genotype, but since this species was declared by its author (Kittl 1899, p. 72) to be a junior synonym of Turbo quadratus Stoppani, the latter must be considered the type species. Because of the absence of a 


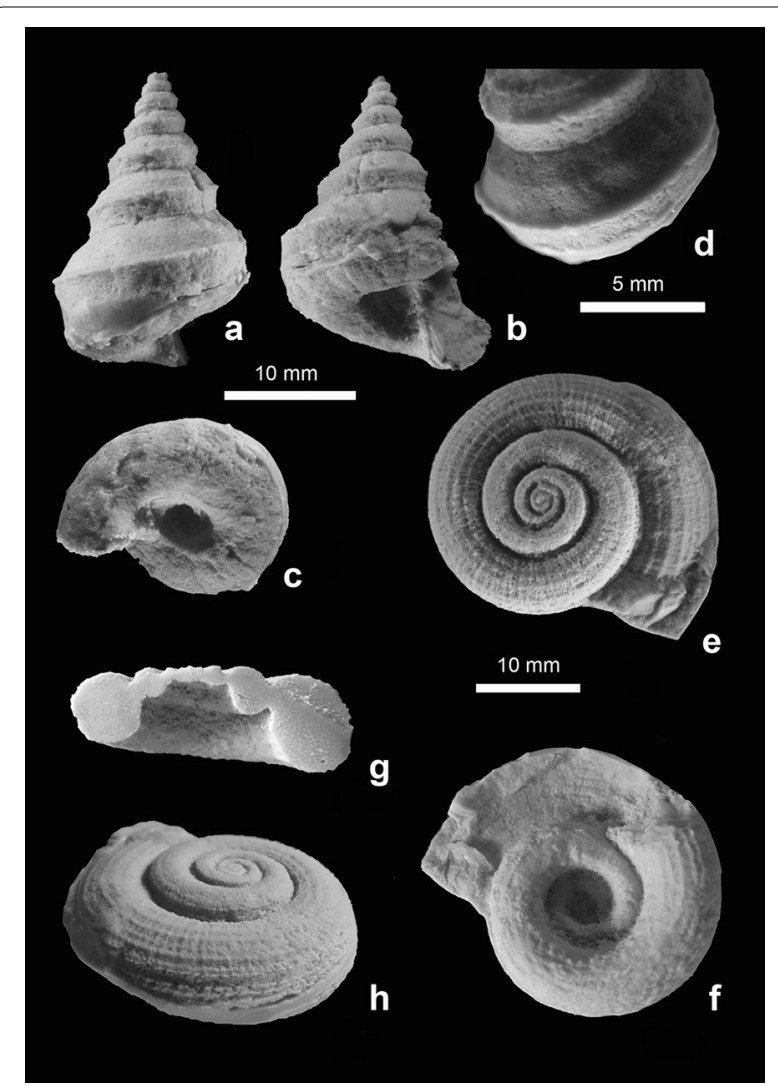

Fig. 3 a-d Worthenia (Humiliworthenia)? aff. microstriata Nützel et al. 2018, Middle Besano Formation, uppermost Anisian. MCSN 3002: a abapertural view, $\mathbf{b}$ apertural view, $\mathbf{c}$ basal view, and $\mathbf{d}$ detail with growth lines on the ramp. e-h Frederikella cf. cancellata (Zardini 1978), Lower Besano Formation, uppermost Anisian. PIMUZ 29952: e apical and $\mathbf{f}$ umbilical view, $\mathbf{g}$ transversal section, $\mathbf{h}$ apical side view. All images have been obtained producing positive silicon casts from negative external mold

holotype, Haas 1953 designated as holotype the specimen depicted by Kittl (1894b, Fig. 12, pl. 3; reproduced by Böhm 1895, textfig. 25, and by Wenz 1938, Fig. 1007).

\section{?Trachynerita sp. Fig. 4a-d}

Material Specimen PIMUZ 37303, preserved partially as external mold and partially as a poorly preserved and slightly deformed shell.

Measurements $\mathrm{D}=20.90 \mathrm{~mm}, 2$ last whorls preserved. $\mathrm{H}=16.60 \mathrm{~mm}$ (first whorls missing); pleural angle $=95^{\circ}$.

Occurrence Point 902/Mirigioli (800 m WSW Monte San Giorgio), Meride, Canton Ticino. Middle Besano Formation (bed 100), Secedensis Zone, uppermost Anisian.
Description The specimen PIMUZ 37303 shows a broadly globular shell with a low spire and gradate shape. The whorls rapidly increase in size and are separated by well-marked suture. The whorl outline is convex. The apex is missing. The suture is slightly impressed. There is a large subsutural flattened ramp, nearly perpendicular to the axis. The abaxial edge of this ramp is a well-marked angular shoulder. For the last whorl, a rounded angulation developed in midwhorl position. The base is rounded convexly and partially covered by matrix. The aperture is obliquely teardropshaped and clearly higher than wide. Prosocline growth lines are poorly preserved on the flanks. Ornaments are not observable.

Remarks This specimen appears quite similar to Trachynerita quadrata (Stoppani, 1858). The type specimen for this taxon, collected from the Esino Limestone, is lost. After intense research in the main gastropod collections it is clear that this species is very rare in the Esino Limestone, while somewhat more common in the Latemar Limestone. Two specimens from the Latemar Limestone, belonging to this taxon, are present in the collection of the Paläontologisches Museum der Universität Zürich (PIMUZ 37301; PIMUZ 37302). A positive comparison has been made between the present specimen and those from the Latemar Limestone. The form illustrated by Leonardi and Fiscon (1959) from the San Cassiano Formation (Carnian) has a general shape similar to Trachynerita quadrata, but differs in having a more convex whorl face and narrower whorls. The specimen illustrated by Nützel \& Senowbari Daryan (1999) from Iran (Norian/ Rhaetian) shows orthocline growth lines, while in the specimens figured by Stoppani (1858) and Kittl (1894b, $1899)$ the growth lines are clearly prosocline. Furthermore, the specimen from Iran has a more inflated last whorl, while the aperture is smaller than that of the type. Very similar to Trachynerita quadrata is the specimen illustrated by Zardini (1985) from the San Cassiano Formation, however this is a juvenile specimen.

\section{Subclass Caenogastropoda Cox, 1960 Clade Hypsogastropoda \\ Unassigned to Superfamily \\ Family Coelostylinidae Cossmann, 1908}

Genus Omphaloptycha (Ammon, 1893) Böhm, 1895

Type species. Chemnitzia (Microschiza) nota Ammon, 1893 
?Omphaloptycha sp. 1 Fig. 4e

Material Specimen PIMUZ 37312, preserved as external mold covered with fine dolomite crystals.

Measurements ca. 7 whorls; $W=20.00 \quad \mathrm{~mm}$; $\mathrm{H}=52.00 \mathrm{~mm}$ (first whorls missing); pleural angle $=30^{\circ}$.

Occurrence Point 902/Mirigioli (800 m WSW Monte San Giorgio), Meride, Canton Ticino. Lower Besano Formation (bed 47), Reitzi Zone, uppermost Anisian.

Description The specimen PIMUZ 37312 shows a conical to slightly pupiform shell. The last whorl occupies approximately two-fifths of the total shell height. The juvenile whorls are flattened, while the last whorls are rounded and slightly convex. The suture is slightly impressed. The base is conoidal with convex wall. The umbilicus is not observable and growth lines are not visible. The whorls appear smooth but their surface is poorly preserved. This specimen appears similar to Omphaloptycha heeri (Kittl, 1894) and in particular to the specimen from the Marmolada Limestone figured by Kittl (1894b, pl. 6, Fig. 17). Böhm (1895) misidentified his specimens generating confusion (see Kittl 1899, p. 114).

?Omphaloptycha sp. 2 Fig. $4 \mathrm{f}-\mathrm{g}$

Material Specimen PIMUZ 29951, preserved as external mold covered with fine dolomite crystals.

Measurements 6 whorls; $\mathrm{W}=24.00 \mathrm{~mm} ; \mathrm{H}=52.00 \mathrm{~mm}$ (first whorls missing); pleural angle $=40^{\circ}$.

Occurrence Point 902/Mirigioli (800 m WSW Monte San Giorgio), Meride, Canton Ticino. Lower Besano Formation (bed 47), Reitzi Zone, uppermost Anisian.

Description The shell is conical and moderately highspired with last whorl about $1 / 2$ of total height. The whorls are flattened to slightly convex. The penultimate whorl is flattened to slightly swollen and the last whorl is slightly inflated. A well-rounded peripheral angle at the midheight of the last whorl distinguishes the flank from the base, and the ramp is flattened and slightly inclined. The suture is shallow but distinct. The base is rounded convexly and conical. The slit-like umbilicus is not observable. The surface of shell is poorly preserved. The aperture is obliquely oval and has an anterior siphonal beak. This specimen appears in general shape similar to Omphaloptycha escheri (Hörnes, 1856).

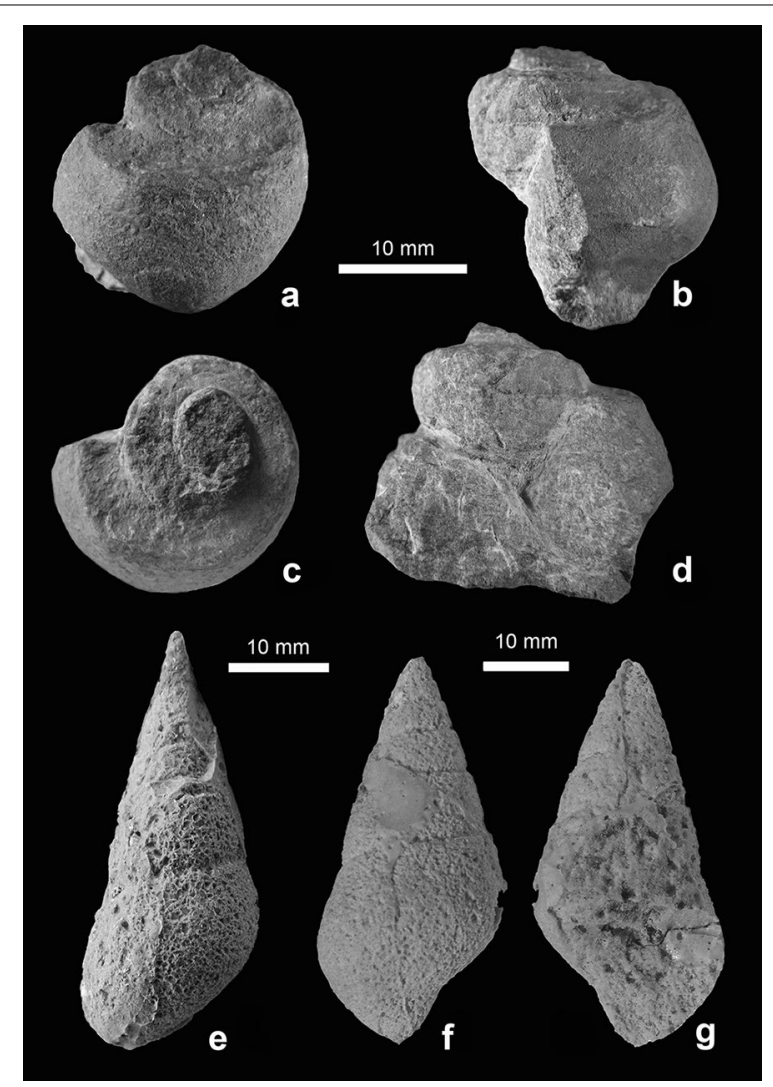

Fig. 4 a-d ?Trachynerita sp., Middle Besano Formation, uppermost Anisian. PIMUZ 37303: a apical side view, b side, c apical, and $\mathbf{d}$ apertural view. e ?Omphaloptycha sp. 1, Lower Besano Formation, uppermost Anisian. PIMUZ 37312: Abapertural view. f, g ?Omphaloptycha sp. 2, Lower Besano Formation, uppermost Anisian. PIMUZ 29951: $\mathbf{f}$ abapertural and $\mathbf{g}$ apertural view. Images a-d have been obtained from original specimen; images $\mathbf{e}-\mathbf{g}$ from silicon casts

\section{Taphonomy and environment}

The gastropods are preserved in the dolomitic beds throughout the Besano Formation, but not in the bituminous shales, a distribution noted as similar to cephalopods (Rieber 1973a). The gastropods are preserved as partly flattened internal molds and external molds imprinting the shell in the finely laminated bituminous dolomites (mudstone), whereas undeformed external molds, partly cemented by dolomite crystals, are typical for the massive dolomite beds (wackestone). Gastropods are relatively common in the upper Besano Formation (mainly beds 173, 163 and 144; Lower Ladinian), but rare in the middle and lower Besano Formation, with the exception of beds 118, 76 and 47 (Upper Anisian; Fig. 1). A maximum of 295 specimens was noted during the excavation in dolomite bed 118 (Middle Besano Formation), however these gastropods are poorly preserved 
and not identifiable. Better preserved molds were found in bed 47 (Lower Besano Formation). Of note is bed 76 with a dense accumulation of juvenile gastropods, found together with cephalopods (ceratitid ammonoids, Fig. 5a), and bed 69 with partly silicified shells of tiny gastropods and ceratitid ammonoids (Fig. 5b).

Benthic molluscs are rarely found in the Besano Formation, which is interpreted as being deposited in an isolated intra-platform basin characterized by usually anoxic conditions (Bernasconi 1991, 1994; Furrer 1995; Röhl et al. 2001; Furrer and Vandelli 2014). The abundance of gastropods correlates partly with the occurrence of cephalopods and dasycladacean algae, but not with that of bivalves (Fig. 1), known mainly from shellbeds in the middle and lower Besano Formation. Rieber (1968, 1973b) suggested that the common bivalve Daonella and the small posidoniids (Peribositra) lived as pseudoplankton attached to floating algae in the surface waters. Schatz (2005a, b) could not find any means to attach to a float in daonellids and proposed that these paper clams lived as epibenthic, pleurothethic organisms on soft, soupy sediments in dysoxic conditions.

However, benthic gastropods could not live on the seabed in the basin due to the usually stagnant, probably hypersaline bottom waters and depletion of oxygen by decaying organic matter. Small gastropods could have lived as pseudoplankton attached to floating algae in the superficial waters, as suggested by Rieber (1973b). The present small turriculate gastropods seem to be larval-postlarval stages belonging to Caenogastropoda, which have a multispiral protoconch. A free-swimming veliger planktotrophic larva occurs in these forms (Ponder and Lindberg 2008; Nützel, 2014). Accumulations of larval specimens suggest unfavorable living conditions with prevailing disturbance in the planktic realm or mass mortality events. Larger gastropods were probably washed in with sediments disturbed by slumping and turbidite currents along the basin edge or by storm activity across the platform. Similar gastropods were found in the time equivalent shallow water carbonates of the middle San Salvatore Dolomite at Rasa di Varese, East of Monte San Giorgio (Pieroni 2011; Pieroni and Nützel 2014) and Monte San Salvatore further North (Rasatomaria gentilii Pieroni and Nützel 2014, unpublished material, collection Zorn 1971).

\section{Conclusion}

The specimens described herein belong to the three main clades of the Class Gastropoda, which characterized the Middle Triassic faunas of the Alps. Despite the scarcity of identifiable gastropods, this limited fauna shows an unexpected biodiversity similar to those of Middle Triassic carbonate platforms of the Southern Alps (e.g. Esino Limestone, Marmolada/Latemar Limestone, see Kittl 1894b, Böhm 1895), as well as the San Cassiano Formation (Carnian, Dolomites, see Kittl 1894a).

True benthic molluscs are very rarely documented in the Besano Formation, which is interpreted as intra-platform basin sediments deposited in usually anoxic condition. Small and juvenile gastropods could have been lived as pseudoplankton attached to floating algae or as freeswimming veliger planktotrophic larval stages. However,

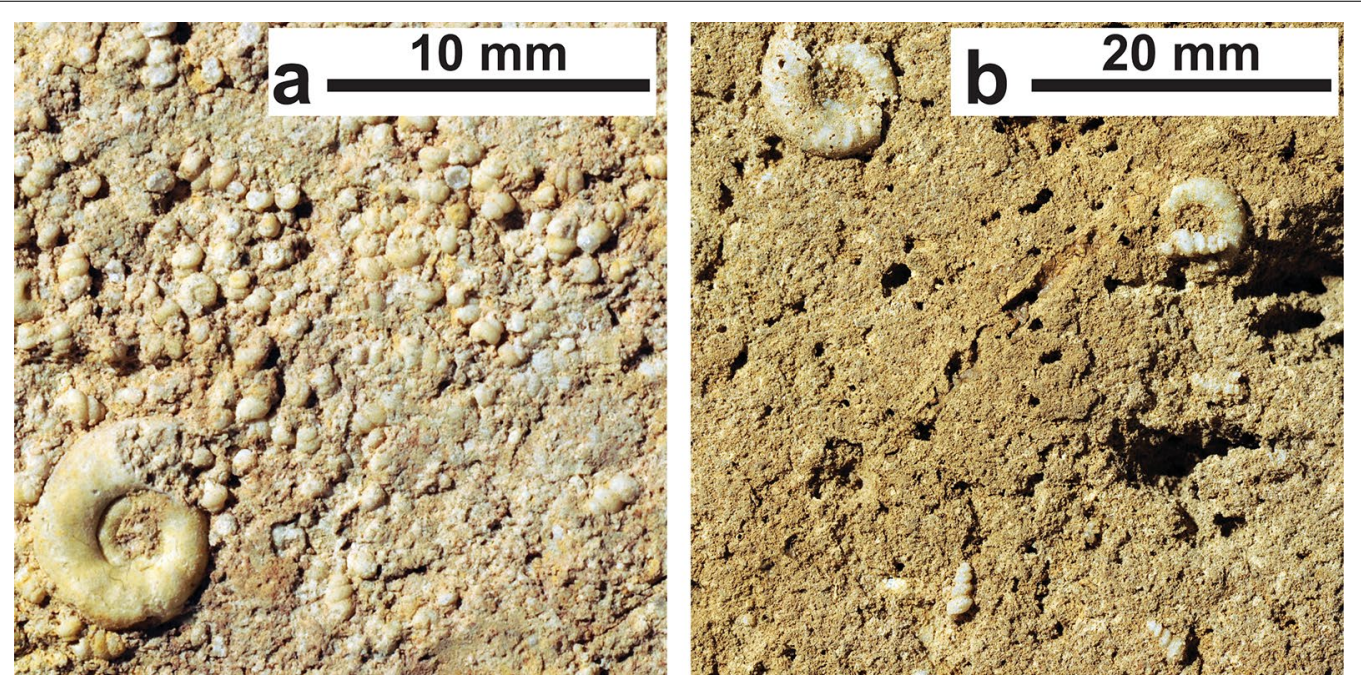

Fig. 5 Accumulations of small turriculate gastropods: larval-postlarval stages belonging to Caenogastropoda: a PIMUZ 37341 with a ceratitid ammonoid (lower left). Point 902/Mirigioli (Monte San Giorgio), Middle Besano Formation (bed 76); b PIMUZ 37340, three silicified gastropods (bottom and upper right) together with two silicified ceratitid ammonoids (Repossia acutenodosa Rieber, 1973). Valle Stelle (Monte San Giorgio), Middle Besano Formation (bed 69) 
larger gastropods more probably were washed in with sediments disturbed by slumping and turbidite currents along the basin edge or storm activity across the platform of the time equivalent Middle San Salvatore Dolomite.

\begin{abstract}
Acknowledgements
The authors are indebted to Christian Klug (PIMUZ) and Rudolf Stockar (MCSN) for the permission to study the specimens here described. We would also like to thank Alexander Nützel (SNSB-Bayerische Staatssammlung für Paläontologie und Geologie, München), and Stefano Monari (Dipartimento di Geoscienze, Università di Padova) for helpful comments on an earlier version of the manuscript. We also thank Hans Rieber (former director of the PIMUZ) for the determination of the ammonoids in Fig. 3b. Sue Beardmore (National Museums Scotland, Edinburgh) improved the English, Gabriel Aguirre (PIMUZ) designed Fig. 1 and Rosi Roth (PIMUZ) made the photographs of Fig. 5. Two anonymous reviewers are thanked for their constructive criticism.
\end{abstract}

\section{Authors' contribution}

VP and HF designed and wrote the study. VP selected, classified and photographed the specimens and treated the systematics of the gastropods. HF contributed with the localities, stratigraphy, taphonomy and environment. Both authors read and approved the final manuscript.

\section{Competing interests}

The authors declare that they have no competing interests.

\section{Author details}

${ }^{1}$ Museo di Storia Naturale "A. Stoppani", Seminario Arcivescovile "Pio XI", Via Papa Pio XI, 32, 21040 Venegono Inferiore, VA, Italy. ${ }^{2}$ Paläontologisches Institut und Museum der Universität Zürich, Karl Schmid-Strasse 4, 8006 Zurich, Switzerland.

Received: 31 October 2019 Accepted: 19 January 2020

Published online: 12 February 2020

\section{References}

Airaghi, C. (1911). Ammoniti degli scisti bituminosi di Besano in Lombardia. Bollettino della Società Geologica Italiana, 30, 1048-1050.

Airaghi, C. (1912). I molluschi degli scisti bituminosi di Besano in Lombardia. Atti della Società italiana di scienze naturali, 51, 1-30.

Bandel, K. (1993). Trochomorpha (Archaeogastropoda) aus den St. CassianSchichten (Dolomiten, Mittlere Trias). Annalen des Naturhistorischen Museums Wien, 95, 1-99.

Bandel, K. (2016). A glimpse into the Jurassic gastropods of the shallow sea with description of Mid-Jurassic species of Madagascar (Sakaraha) and their relation to species of similar age in Europe and elsewhere. Paläontologie, Stratigraphie, Fazies (23), Freiberger Forschungshefte, C, 550, 137-203.

Bassani, F. (1886). Sui fossili e sull'età degli schisti bituminosi triassici di Besano in Lombardia. Atti della Società italiana di scienze naturali, 29, 15-72.

Bernasconi, S. M. (1991). Geochemical and microbial controls on Dolomite Formation and organic matter production/preservation in anoxic environments: a case study from the Middle Triassic Grenzbitumenzone, Southern Alps (Ticino, Switzerland). Swiss Federal Institute of Technology Zurich. Degree of Doctor of Natural Sciences, p. 171

Bernasconi, S. M. (1994). Geochemical and microbial controls on dolomite formation in anoxic environments. A case study from the middle Triassic (Ticino, Switzerland). Contributions to Sedimentology, 19, 1-109.

Böhm, J. (1895). Die Gastropoden des Marmolatakalkes. Palaeontographica, 42, 211-308.

Conrad, T. A. (1835). Description of five new species of fossil shells in the collection presented by Mr. Edward Miller to the Geological Society. Transactions of the Geological Society of Pennsylvania, 1, 267-270.

Cossmann, M. (1908). [Review of] Système silurien du centre de la Bohème, 1 ère partie. Recherches paléontologiques. Vol. IV: Gastropodes, T. II, par J. Perner. Revue Critique de Paléozoologie, 12(2), 91-95. de Koninck, L. G. (1883). Faune du calcaire carbonifére de la Belgique, quatrième partie. Gastéropodes. Musée Royal d'Histoire Naturelle de Belgique Annales, Série Paléontologique, 8, 1-240.

Furrer, H. (1995). The Kalkschieferzone (Upper Meride Limestone) near Meride (Canton Ticino, Southern Switzerland) and the evolution of a Middle Triassic intraplatform basin. Eclogae Geologicae Helvetiae, 88(3), 827-852.

Furrer, H. (2003). Der Monte San Giorgio im Südtessin—Vom Berg der Saurier zur Fossil-Lagerstätte internationaler Bedeutung. Neujahrsblatt der Naturforschenden Gesellschaft Zürich, 206, 1-64.

Furrer, H. \& Vandelli, A. (2014). Guide to the museum of fossils from Monte San Giorgio Meride (p. 128). Meride: Fondazione del Monte San Giorgio. ISBN: 978-88-940067-2-8

Gründel, J. (1998). Archaeo- und Caenogastropoda aus dem Dogger Deutschlands und Nordpolens (Archaeo- and Caenogastropoda from the Dogger of Germany and Northern Poland). Stuttgarter Beiträge zur Naturkunde, B (Geologie und Paläontologie), 260, 1-22.

Hörnes, M. (1856). Über Gastropoden aus der Trias der Alpen. Denkschriften der Kaiserlichen Akademie der Wissenschaften, Mathematik und Naturkunde Classe, 12(2), 21-34.

Kittl, E. (1894a). Die Gastropoden der Schichten von St. Cassian der südalpinen Trias. Teil III. Annalen des Kaiserlich-Königlichen Naturhistorischen Hofmuseum, 9, 144-277.

Kittl, E. (1894b). Die triadischen Gastropoden der Marmolata und verwandter Fundstellen in den weissen Riffkalken Südtirols. Kaiserlich-Königlich Geologische Reichsanstalt, Jahrbuch, 44, 99-182.

Kittl, E. (1899). Die Gastropoden der Esinokalke nebst einer Revision der Gastropoden der Marmolatakalke. Annalen des Kaiserlich-Königlichen Naturhistorischen Hofmuseum, 14, 1-237.

Knight, J. B., Cox, L. R., Keen, A. M., Smith, A. G., Batten, R. L., Yochelson, E. L, et al. (1960). Mollusca - General features, Scaphopoda, Amphineura, Monoplacophora, Gastropoda_-General features, Archaeogastropoda and some Caenogastropoda and Opisthobranchia. In R. C. Moore (Ed.), Treatise on Invertebrate Paleontology. Part I, Mollusca 1 (p. 351). New York: Geological Society of America and University of Kansas Press.

Koken, E. (1900). Über triassische Versteinerungen aus China. Neues Jahrbuch für Mineralogie, Geologie und Paläontologie, 1900(1901), 186-215.

Leonardi, P., \& Fiscon, F. (1959). La fauna cassiana di Cortina d'Ampezzo. Parte III: Gasteropodi. Memorie degli Istituti di Geologia e Mineralogia dell'Università diPadova, 21, 1-103.

López-Arbarello, A., Bürgin, T., Furrer, H., \& Stockar, R. (2016). New holostean fishes (Actinopterygii: Neopterygii) from the Middle Triassic of the Monte San Giorgio (Canton Ticino, Switzerland). PeerJ, 4, e2234. https://doi. org/10.7717/peerj.2234.

Nützel, A. (2014). Larval ecology and morphology in fossil gastropods. Palaeontology, 57(3), 479-503.

Nützel, A., Kaim, A., \& Grădinaru, E. (2018). Middle Triassic (Anisian, Bithynian) gastropods from North Dobrogea (Romania) and their significance for gastropod recovery from the end-Permian mass extinction event. Papers in Palaeontology, 4, 477-512.

Nützel, A., \& Senowbari-Daryan, B. (1999). Gastropods from the Late Triassic (Norian-Rhetian) Nayband Formation of central Iran. Beringeria, 23, 93-132.

Pieroni, V. (2011). La Rasa di Varese e i suoi fossili (p. 157). Varese: Pietro Macchione.

Pieroni, V., \& Nützel, A. (2014). Rasatomaria gentilii gen. n. n. sp.—A new Middle Triassic pleurotomarioid gastropod genus and species from Rasa di Varese (San Salvatore Formation, southern Alps). Rivista Italiana di Paleontologia e Stratigrafia, 120(3), 281-286.

Ponder, W. F., \& Lindberg, D. L. (2008). Phylogeny and evolution of the Mollusca (p. 469). Berkeley: University of California Press.

Rieber, H. (1965). Zur Wirbellosen-Fauna der Grenzbitumenzone der mittleren Trias des Monte San Giorgio (Kt. Tessin, Schweiz). Eclogae Geologicae Helvetiae, 58, 1083-1092.

Rieber, H. (1968). Die Artengruppe der Daonella elongata Mojsisovics. aus der Grenzbitumenzone der mittleren Trias des Monte San Giorgio (Kanton Tessin, Schweiz). Paläontologische Zeitschrift, 42, 33-61.

Rieber, H. (1969). Daonellen aus der Grenzbitumenzone der mittleren Trias des Monte San Giorgio (Kanton Tessin, Schweiz). Eclogae Geologicae Helvetiae, 62(2), 657-683. 
Rieber, H. (1970). Phragmoteuthis? ticinenesis n. sp., ein Coleoidea-Rest aus der Grenzbitumenzone (Mittlere Trias) des Monte San Giorgio (Kt. Tessin, Schweiz). Paläontologische Zeitschrift, 44(1), 32-40.

Rieber, H. (1973a). Die Triasfauna der Tessiner Kalkalpen. XXII, Cephalopoden aus der Grenzbitumenzone der mittleren Trias des Monte San Giorgio (Kt. Tessin, Schweiz). Schweizerische Paläontologische Abhandlungen, 93, 1-96.

Rieber, H. (1973b). Ergebnisse paläontologisch-stratigraphischer Untersuchungen in der Grenzbitumenzone (Mittlere Trias) des Monte San Giorgio (Kanton Tessin, Schweiz). Eclogae Geologicae Helvetiae, 66(3), 667-685.

Rieber, H. (1974a). Breviconoteuthis breviconus (Reis), ein Phragmoteuthide aus der mittleren Trias des Monte San Giorgio (Kanton Tessin, Schweiz). Neues Jahrbuch für Geologie und Paläontologie Monatshefte, 7, 415-421.

Rieber, H. (1974b). Ammoniten und Stratigraphie der Grenzbitumenzone (Mittlere Trias) der Tessiner Kalkalpen. In H. Zapfe (Ed.): Die Stratigraphie der alpin-mediterranen Trias. Schriftenreihe Erdwissenschaftliche Kommunikation der Österreichischen Akademie der Wissenschaften, 2, 167-176.

Röhl, H. J., Schmid-Röhl, A., Furrer, H., Frimmel, A., Oschmann, W., \& Schwark, L. (2001). Microfacies, geochemistry and palaeoecology of the Middle Triassic Grenzbitumenzone from Monte San Giorgio (Canton Ticino, Switzerland). Geologia Insubrica, 6(1), 1-13.

Schatz, W. (2005a). Palaeoecology of the Triassic black shale bivalve DaonellaNew insights into an old controversy. Palaeogeography, Palaeoclimatology, Palaeoecology, 216(3), 189-201.

Schatz, W. (2005b). Taxonomie, Paläoökologie und biostratigraphische Anwendung der Daonellen (Bivalvia, Mollusca) aus der Mitteltrias Europas. Schweizerische Paläontologische Abhandlungen, 125, 1-179.

Stoppani, A. (1858-60). Les pétrifications d'Esino ou description des fossiles appartenants au dépôt triasique supérieur des environs d'Esino en Lombardie.
In A. Stoppani (1858-1881): Paléontologie Lombarde ou description des fossiles de Lombardie, 1. Milano: Joseph Bernardoni (p. 151).

von Ammon, L. (1892/1893). Die Gastropoden des Hochfellen-Kalkes und über Gastropoden-Reste aus Ablagerungen von Adnet, von Monte Nota und den Raibler Schichten. Geognostische Jahreshefte, 5, 161-219.

von Salvini-Plawen, L. (1980). A reconsideration of systematics in the Mollusca (Phylogeny and higher classification). Malacologia, 19(2), 249-278.

von Zittel, K. A. (1895). Grundzüge der Paläontologie (Paläozoologie), Abt. I, Invertebrata (p. 971). München and Leipzig: Oldenburg.

Wenz, W. (1938). Gastropoda. Handbuch der Paläozoologie, 6. Berlin, p. 1639.

Yin, N. H. F., \& Yochelson, E. L. (1983). Middle Triassic Gastropoda from Qingyan, Guizhou Province, China; 1, Pleurotomariacea and Murchisoniacea. Journal of Paleontology, 57, 162-187.

Zardini, R. (1978). Atlante dei gasteropodi della Formazione di San Cassiano raccolti nella regione dolomitica attorno a Cortina d'Ampezzo. Fossili Cassiani, 1-58.

Zardini, R. (1985). Primo aggiornamento all'Atlante dei bivalvi e secondo aggiornamento all'Atlante dei gasteropodi con illustrazioni dei gusci che hanno conservato la pigmentazione originaria. Fossili raccolti nella Formazione di San Cassiano della regione dolomitica attorno a Cortina d'Ampezzo. Fossili Cassiani. 1-17.

\section{Publisher's Note}

Springer Nature remains neutral with regard to jurisdictional claims in published maps and institutional affiliations.

\section{Submit your manuscript to a SpringerOpen ${ }^{\circ}$ journal and benefit from:}

- Convenient online submission

- Rigorous peer review

- Open access: articles freely available online

- High visibility within the field

- Retaining the copyright to your article

Submit your next manuscript at $\gg$ springeropen.com 